ЕНЕРГЕТИКА

UDC 539.4

O. Maslo,

P. Bulah, $\mathrm{PhD}$,

G. Chyzhyk, $\mathrm{PhD}$,

A. Shyrokov, $\mathrm{PhD}$,

A. Byalonovich, $\mathrm{PhD}$

G.S. Pisarenko Institute for Problems of Strength of the National Academy of Science of Ukraine, 2 Timiryazevs’ka Str., Kyiv, Ukraine, 01014; e-mail: pavelbulakh@gmail.com

\title{
PRINCIPLES OF REPRESENTATIVE
}

\section{THERMOHYDRAULICAL SCENARIOS CHOOSING USED FOR STRENGTH SIMULATION OF NPP UNITS}

О.М. Масло, П.О.Булах, Г.В.Чижик, А.В. Широков, А.В. Бялонович. Принципи відбору представницьких теплогідравлічних сценаріїв при виконанні розрахунків на міцність обладнання АЕС. Безпечна експлуатація основного обладнання атомних електростанцій (AЕC) потребує проведення періодичної оцінки таких факторів, як величина накопиченої втомної пошкоджуваності елементів конструкцій та ії прогнозоване значення на розрахунковий період подальшої експлуатації. Аналіз тепломеханічного впливу регламентованих режимів експлуатації на міцність елементів конструкцій та вузлів устаткування $\epsilon$ одним з важливих етапів продовження ресурсу експлуатації АЕС. При цьому для одного режиму роботи обладнання, як правило, розглядаються декілька варіантів (сценаріїв) його протікання, кожен 3 яких характеризується унікальною сукупністю параметрів тепломеханічного впливу на обладнання, таких як тиск, температура, швидкість витрати теплоносія та ін. Велика кількість таких варіантів у підсумку може призводити до значних витрат часу та обчислювальних ресурсів. Метою даного дослідження $\epsilon$ розробка принципів відбору представницьких теплогідравлічних сценаріїв при виконанні розрахунків на визначення прогнозованого значення втомної пошкоджуваності обладнання АЕС. В представленому дослідженні показано, що на основі математично обгрунтованого порівняння можливе суттєве скорочення кількості необхідних для аналізу сценаріїв шляхом виключення 3 подальшого розгляду непредставницьких варіантів. Описано основні принципи відбору теплогідравлічних сценаріїв на прикладі застосування іх для розрахунку на міцність компенсатора тиску реактора AEC типу ВBEР-1000. Наведено чисельні параметри оцінки графіків вказаних типових сценаріїв, які дозволяють визначити представницькі сценарії з групи близьких за характером протікання процесів. Точність отриманих результатів при відборі представницьких теплогідравлічних сценаріїв знаходиться на достатньому рівні відповідно до їх повного аналізу, що дозволяє рекомендувати запропонований підхід для використання.

Ключові слова: ресурс, теплогідравлічні режими, принципи відбору сценаріїв

O. Maslo, P. Bulah, G. Chyzhyk, A. Shyrokov, A. Byalonovich. Principles of representative thermohydraulical scenarios choosing used for strength simulation of NPP units. Safe operation of main equipment of nuclear power plants requires periodic estimation of such factors as size of accumulated fatigue damages of elements constructions and predicted value of fatigue damage on rated period of future operation. One of the most important stages of nuclear power plant resource prolongation is analysis of thermomechanical influence of the operational regimes on the strength of the elements and its units. Herewith for one of the element operational regimes a couple of several variations are performed, each of which is characterized by its unique set of thermomechanical parameters, such as pressure, temperature, velocity of coolant consumption, etc. A huge amount of such variations can increase of calculation time and software requirements. The main goal of this research is decreasing of amount of thermohydraulic scenarios justification of possible operational regimes of main equipment of nuclear power plants that are subjected by full analysis during possible amount of fatigue damages determination. This research describes a possibility of decreasing amount of required simulations using reasonable exclusion of unrepresentative variants on the basis of mathematic based comparison. This paper described main principles of thermohydraulical scenarios while using this methodic for strength simulation of pressure compensator of nuclear power plants with WWER-1000. The numerical parameters for estimation on typical scenarios diagrams are performed, and it gives a possibility to determine reasonable scenarios from groups that are close by their character of simulated processes. The accuracy of obtained data during reasonable thermohydraulical scenarios is at satisfactory level according to its total analysis, and it gives possibility to recommend the proposed approach for usage.

Keywords: resource, thermohydraulical regimes, principles of scenarios choosing

\section{DOI: 10.15276/opu.3.59.2019.02}

(c) 2019 The Authors. This is an open access article under the CC BY license (http://creativecommons.org/licenses/by/4.0/). 
Introduction. Nuclear and radiation safety standards require the high reliability of existing NPP equipment, especially in the case of its off-site operation. To do this, periodically assess the residual life of the responsible equipment. A similar assessment can also be made to take into account important safety and reliability factors that have occurred at work.

Research analysis and problem statement. One of the stages of the NPP equipment resource assessment is the analysis of the thermomechanical influence of the regulated operating modes on the strength of the structural elements and components of the equipment.

This influence is determined by the joint action of such basic performance characteristics as the rate of change of temperature, its maximum and minimum value, pressure, the rate of consumption of the coolant, etc. As stated in the Nuclear Energy Agency CSNI report("Validation matrix for thermalhydraulic codes for VVER LOCA and transients”: 2001, P. 249), this applies to operating modes of equipment whose leak analysis is critical to the assessment safety, in particular, emergency modes and transients associated with the loss of coolant. Also, the variability of the operating modes may be caused by the need to work out the parameters of normal operating conditions for this equipment [1].

The need to analyze a large number of modes with similar conditions of the flow of thermalhydraulic processes is associated with the development of the functionality of software packages designed to numerically simulate these processes [2-6].

In the case where the flow of one mode is considered in several variants (scenarios), a significant reduction of the number of scenarios necessary for its analysis can be eliminated by eliminating nonrepresentative variants from further consideration.There is insufficient information in the literature regarding such optimization. Therefore, the formation of principles for the selection of representative heat-hydraulic scenarios is an important and relevant task today. One solution to this problem is given in this paper.

The main parameters characterizing the influence of external loading on the equipment are the pressure and temperature in its elements. The initial data for the analysis of scenarios of working modes of hydroelements of equipment are the results of their thermal and hydraulic calculations.

Pressure and temperature during the calculated time are presented in tables of discrete values. This allows for comparative analysis and graphical representation of the calculation modes in data analysis packages. The peculiarity of thermo-hydraulic calculations is that the estimated time for different scenarios of the same operating mode of the equipment may differ significantly. This is due to the fact that the heat and hydraulic calculations used in the analysis were carried out until the pressure and temperature values stabilized.

The purpose of this study is to develop principles for the selection of representative heat and hydraulic scenarios when performing calculations to determine the predicted value of fatigue damage to nuclear power plant equipment.

For this purpose it is necessary to select criteria for selection of representative scenarios, to develop the basic principles of exclusion of non-representative variants from further consideration and to determine the possibility of calculating only representative scenarios, by comparison with the results of a complete analysis of the accumulated fatigue damage of the responsible structural elements.

The main stages of comparative analysis. Graphical representation and benchmarking are performed for groups of scenarios that relate to one design mode of operation of the equipment.

When comparing thermal-hydraulic scenarios, the following parameters were determined:

1. Maximum $\left(P_{\max }, T_{\max }\right)$ and minimum values $\left(P_{\min }, T_{\min }\right)$ of pressure and temperature throughout the estimated time of each scenario;

2. The magnitude of the pressure values $(\Delta P)$ and temperature $(\Delta T)$ as the difference between the maximum and minimum values;

3 . The rate of change of pressure $(\delta P)$ and temperature $(\delta T)$, which in the case of a discrete representation of the studied quantities are characterized by the rate of change of magnitude between two adjacent points of the graph;

4. The presence of local extremes or fluctuations in pressure / temperature;

5. Availability of pressure / temperature plots with oscillations;

6 . The length of the graph of pressure / temperature during the calculated time in conventional units ( $L_{\Sigma P}$ and $L_{\Sigma T}$, respectively). 
The listed parameters 1 - 6 were determined for the whole group of heat-hydraulic scenarios under analysis.

First of all, the scenario was chosen as representative for parameters $1-3$, with maximum values of the range of values of pressure / temperature, the speed of their change.

Further, on the basis of consideration of the above parameters 4-6 and their comparison in the above sequence, a group of representative heat-hydraulic scenarios was determined to further determine their impact on the equipment VAT. An important criterion for inclusion in the list of representative scenarios for which the pressure / temperature ranges and their rate of change do not reach maximum values is the presence on the graphs of sites with local extremes and oscillations, which can have a significant impact on the equipment VAT and accumulated fatigue.

According to this scheme, the characteristic thermal-hydraulic scenarios of the modes of operation of the pressure compensator (PC) of the VVER-1000 reactor were carried out.

Research results. The following are some typical examples of excluding non-representative scenarios of the work of the pressure compensator for the modes "Separation of the cover of the steam generator (SG) collector" and "Breaking of the steam line" according to the proposed scheme.

Thermal-hydraulic scenarios of operation of the pressure compensator for the mode "Separation of the cover of the collector of the steam generator" (Fig. 1, 2 and Table 1) are characterized by significant changes in both pressure and temperature throughout the estimated time. According to the above principles, scenario 1 was excluded from further consideration, as it is characterized by less local pressure fluctuations and is therefore less representative of scenario 2 .

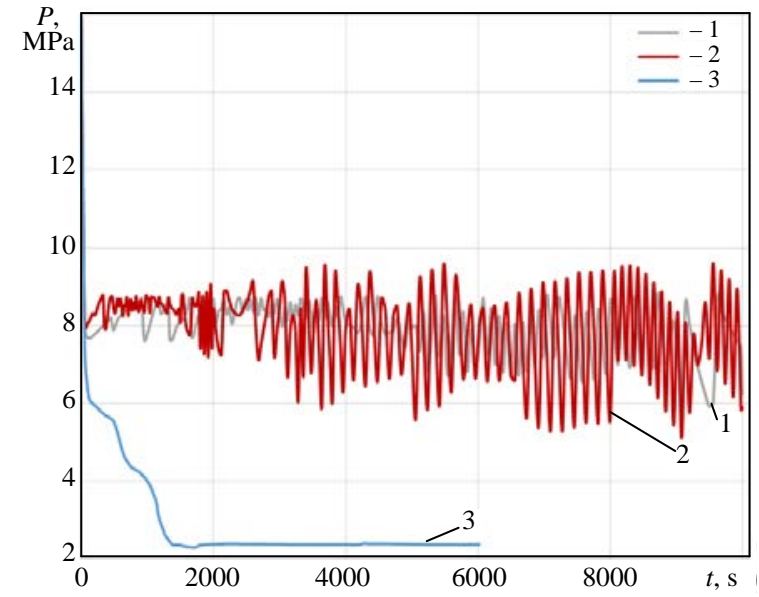

Fig. 1. Graphs of pressure change in the calculated thermal-hydraulic scenarios of the work of the pressure compensator for the mode "Separation of the cover of the collector of the steam generator"

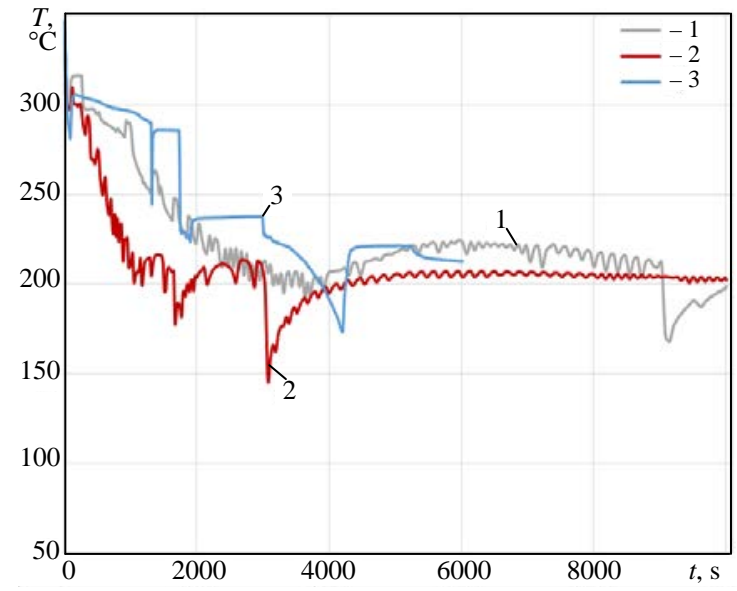

Fig. 2. Graphs of temperature change in the calculated heat and hydraulic scenarios of the pressure compensator operation for the mode "Separation of the cover of the steam generator collector"

Table 1

Numerical characteristics of graphs of pressure and temperature in the calculated thermal and hydraulic scenarios of the PC operation for the mode "Separation of the cover of the SG collector"

\begin{tabular}{c|c|c|c|c|c|c|c}
\hline \multirow{2}{*}{ Parameters } & \multicolumn{3}{|c|}{ Curve on Fig. 1 } & \multirow{2}{*}{ Parameters } & \multicolumn{3}{c}{ Curve on Fig. 2} \\
\cline { 2 - 4 } \cline { 6 - 8 } & 1 & 2 & 3 & & 1 & 2 & 3 \\
\hline $\max \delta P, \mathrm{MPa} / \mathrm{s}$ & 0.046 & 0.089 & 0.001 & $\max \delta T,{ }^{\circ} \mathrm{C} / \mathrm{s}$ & 0.79 & 0.67 & 3.52 \\
\hline $\min \delta P, \mathrm{MPa} / \mathrm{s}$ & -0.296 & -0.242 & -0.296 & $\min \delta T,{ }^{\circ} \mathrm{C} / \mathrm{s}$ & -1.35 & -1.47 & -4.56 \\
\hline$L_{\Sigma P}, \mathrm{c} . \mathrm{u}$. & 10001.84 & 10006.41 & 6020.726 & $L_{\Sigma T}$, c.u. & 10125.24 & 10180.74 & 6173.73 \\
\hline$P_{\max }, \mathrm{MPa}$ & 15.949 & 15.949 & 15.949 & $T_{\max },{ }^{\circ} \mathrm{C}$ & 346.13 & 346.13 & 346.13 \\
\hline$P_{\min }, \mathrm{MPa}$ & 5.921 & 5.115 & 2.294 & $T_{\min },{ }^{\circ} \mathrm{C}$ & 167.87 & 146.71 & 173.50 \\
\hline$\Delta P, \mathrm{MPa}$ & 10.028 & 10.834 & 13.655 & $\Delta T,{ }^{\circ} \mathrm{C}$ & 178.24 & 199.42 & 172.63 \\
\hline
\end{tabular}


Thermal-hydraulic scenarios of the work of the pressure compensator for the mode "Steam line break" (Figs. 3, 4 and Table 2) are characterized by noticeable changes in temperature and pressure increase during the estimated time for all scenarios. Scenario 3 was selected as representative for this scenario group, characterized by maximum pressure and temperature variations during the estimated time.

Table 2

Numerical characteristics of the pressure and temperature graphs in the calculated thermal and hydraulic scenarios of the pressure compensator operation for the steam line break mode

\begin{tabular}{c|c|c|c|c|c|c|c}
\hline \multirow{2}{*}{ Parameters } & \multicolumn{3}{|c|}{ Curve on Fig. 3} & \multirow{2}{*}{ Parameters } & \multicolumn{3}{c}{ Curve on Fig. 4} \\
\cline { 2 - 4 } \cline { 6 - 8 } & 1 & 2 & 3 & & 1 & 2 & 3 \\
\hline $\max \delta P, \mathrm{MPa} / \mathrm{s}$ & 0.003 & 0.003 & 0.004 & $\max \delta T,{ }^{\circ} \mathrm{C} / \mathrm{s}$ & 0.49 & 0.49 & 0.12 \\
\hline $\min \delta P, \mathrm{MPa} / \mathrm{s}$ & -0.326 & -0.325 & -0.082 & $\min \delta T,{ }^{\circ} \mathrm{C} / \mathrm{s}$ & -2.73 & -2.64 & -0.44 \\
\hline$L_{\Sigma \mathrm{P}}, \mathrm{C.u}$. & 5000.24 & 5000.24 & 5050.05 & $L_{\Sigma T}$, C.u. & 5023.53 & 5022.97 & 5072.64 \\
\hline$P_{\max }, \mathrm{MPa}$ & 16.025 & 16.025 & 17.941 & $T_{\max },{ }^{\circ} \mathrm{C}$ & 341.97 & 341.97 & 346.29 \\
\hline$P_{\min }, \mathrm{MPa}$ & 10.009 & 9.995 & 10.505 & $T_{\min },{ }^{\circ} \mathrm{C}$ & 141.07 & 138.21 & 117.93 \\
\hline$\Delta P, \mathrm{MPa}$ & 6.016 & 6.030 & 7.437 & $\Delta T,{ }^{\circ} \mathrm{C}$ & 200.89 & 203.75 & 228.36 \\
\hline
\end{tabular}

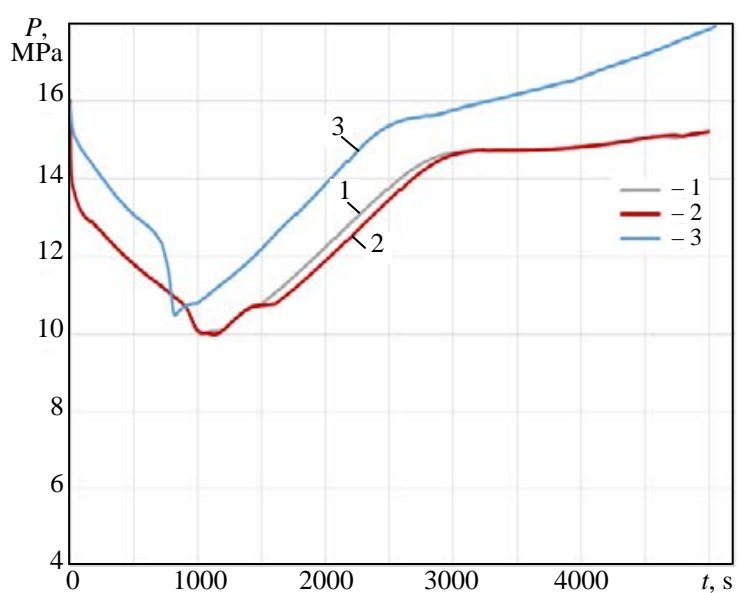

Fig. 3. Graphs of pressure change in the calculated thermal-hydraulic scenarios of the work of the pressure compensator for the mode "The steamline breach"

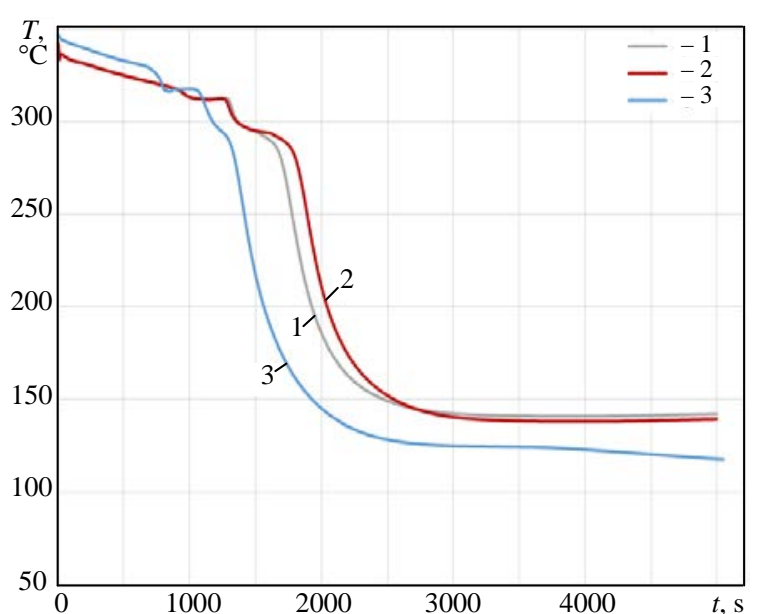

Fig. 4. Graphs of temperature change in the calculated thermal and hydraulic scenarios of the pressure compensator operation for the mode "Steam line rupture"

Thus, in the two cases cited, six non-representative variants were excluded from the six scenarios, which significantly reduced the scope of further analysis.

Determination of accumulated fatigue damage in the short and complete analysis showed a high convergence of results. This confirms the possibility of using the proposed principles for the selection of representative heat and hydraulic scenarios and helps to significantly reduce the calculation time for the strength of NPP equipment.

Conclusions. The basic principles of selection of representative heat-hydraulic scenarios in calculating the strength of NPP equipment are presented in the paper. Using this approach can significantly reduce the amount of data processed and, accordingly, reduce the time of analysis of thermalhydraulic scenarios. The accuracy of the results obtained in the selection of representative thermalhydraulic scenarios is sufficient, according to their complete analysis, which makes it possible to recommend the proposed approach for use. 


\section{Література}

1. Фадеев И.Д., Дмитриева И.В., Рогожкин С.А., Шепелев С.Ф. Обобщение опыта пуска РУ БН-800 для обоснования теплогидравлических параметров в режимах нормальной эксплуатации. Безопасность, эффективность и экономика атомной енергетики: пленарные и секционные док. XI междунар. науч.-тех. конф., г.Москва, 23-24 мая 2018 г. Москва, 2018. С. 587-590.

2. Численное моделирование теплогидравлических процессов в верхней камере быстрого реактора / С.А. Рогожкин, С.Л. Осипов, И.Д. Фадеев, С.Ф. Шепелев, А.А. Аксенов, С.В. Жлуктов, М.Л. Сазонова, В.В. Шмелев. Атомная энергия. 2013. Т. 115, Вып. 5. С. 295-298.

3. Расчетный комплекс для задач обоснования безопасности аэс при запроектных и тяжелых авариях / А.Е. Киселев, К.С. Долганов, Д.Ю. Томащик, Р.И. Бакин, А.А. Киселев, С.Н. Красноперов. Безопасность, эффективность и экономика атомной енергетики: пленарные и секционные док. XI междунар. науч.-тех. конф., г.Москва, 23-24 мая 2018 г. Москва, 2018. С. 446-449.

4. Yuchuan Guo, Guanbo Wang, Dazhi Qian, Heng Yu, Bo Hu, Simao Guo, Xiangmiao Mi, Jimin Ma. Accident safety analysis of flow blockage in an assembly in the JRR-3M research reactor using system code RELAP5 and CFD code FLUENT. Annals of Nuclear Energy. 2018, Vol. 122, P. 125-136.

5. Li Lei, Zhang Zhijian. Development of Thermal-Hydraulic Analysis Code for Plate Type Fuel Reactor 18th International Conference on Nuclear Engineering: Volume 2 Xi'an, China, May 17-21, 2010, P. 497-505.

6. Daeseong Jo, Jonghark Park, Heetaek Chae. Development of thermal hydraulic and margin analysis code for steady state forced and natural convective cooling of plate type fuel research reactors. Progress in Nuclear Energy. 2014, Vol. 71, P. 39-51.

\section{References}

1. Fadeev, I.D., Dmitrieva, I.V., Rogozhkin, S.A., \& Shepelev, S.F. (2018). Generalization of the start-up experience of the BN-800 RP to substantiate thermal-hydraulic parameters in normal operation. Safety, efficiency and economics of nuclear energy: plenary and sectional docs. XI Intern. scientific-tech Conf., (pp. 587-590). Moscow.

2. Rogozhkin, S.A., Osipov, S.L., Fadeev, I.D., Shepelev, S.F., Aksenov, A.A., Zhluktov, S.V., Sazonova, M.L., \& Shmelev, V.V. (2013). Numerical simulation of thermo-hydraulic processes in the upper chamber of the fast reactor. Atomic Energy, 115, 5, 295-298.

3. Kiselev, A.E., Dolganov, K.S., Tomaschik, D.Yu., Bakin, R.I., Kiselev, A.A., \& Krasnoperov, S.N. (2018). Calculation complex for the problems of justifying the safety of NPP in case of beyond design basis and severe accidents. Safety, efficiency and economics of nuclear power engineering: plenary and sectional docks. XI Intern. scientific-tech Conf. (pp. 446-449). Moscow.

4. Yuchuan Guo, Guanbo Wang, Dazhi Qian, Heng Yu, Bo Hu, Simao Guo, Xiangmiao Mi, \& Jimin Ma. (2018). Accident safety analysis of flow blockage in an assembly in the JRR-3M research reactor using system code RELAP5 and CFD code FLUENT. Annals of Nuclear Energy, 122, 125-136.

5. Li Lei, \& Zhang Zhijian. (2010). Development of Thermal-Hydraulic Analysis Code for Plate Type Fuel Reactor, 18th International Conference on Nuclear Engineering: Volume 2 Xi'an, (pp. 497-505). China.

6. Daeseong Jo, Jonghark Park, \& Heetaek Chae. (2014). Development of thermal hydraulic and margin analysis code for steady state forced and natural convective cooling of plate type fuel research reactors Progress in Nuclear Energy, 71, 39-51.

Масло Олександр Миколайович; Maslo Oleksandr, ORCID: https://orcid.org/0000-0003-3822-2883

Булах Павло Олександрович; Bulakh Pavlo, ORCID: https://orcid.org/0000-0001-7252-6683

Чижик Ганна Василівна; Chyzhyk Ganna, ORCID: http://orcid.org/0000-0003-0561-7651

Широков Андрій Володимирович; Shirokov Andrii, ORCID: https://orcid.org/0000-0002-3734-6377

Бялонович Андрій Володивирович; Byalonovich Andrii, ORCID: https://orcid.org/0000-0003-2527-4254

Received September 02, 2019

Accepted November 03, 2019 